\title{
Synthesis and DPPH scavenging assay of reserpine analogues, computational studies and in silico docking studies in AChE and BChE responsible for Alzheimer's disease
}

\author{
Muhammad Yar,"*, Muhammad Arshad ${ }^{3}$, Ariba Farooq ${ }^{1}$, Mazhar Amjad Gilani², Khurshid Ayub ${ }^{3,4}$, \\ Asma Ejaz ${ }^{5}$, Anupriya Kumar ${ }^{6}$, Ichiya Ninomiya ${ }^{5}$ \\ ${ }^{1}$ Interdisciplinary Research Centre in Biomedical Materials, COMSATS Institute of Information Technology, Lahore, Pakistan, \\ ${ }^{2}$ Department of Chemical Engineering, COMSATS Institute of Information Technology, Lahore, Pakistan, ${ }^{3}$ Department of \\ Chemistry, COMSATS Institute of Information Technology, Abbottabad, Pakistan, ${ }^{4}$ Department of Chemistry, College of \\ Science, King Faisal University, Al-Ahsa, Kingdom of Saudi Arabia, ${ }^{5}$ International Center for Chemical and Biological \\ Sciences, Hussain Ibrahim Jamal Research Institute of Chemistry, University of Karachi, Karachi, Pakistan, 'Institute of \\ Transformative Bio-Molecules (WPI-ITbM), Nagoya University, Nagoya, Japan
}

\begin{abstract}
Alzheimer's disease (AD) is a fast growing neurodegenerative disorder of the central nervous system and anti-oxidants can be used to help suppress the oxidative stress caused by the free radicals that are responsible for $\mathrm{AD}$. A series of selected synthetic indole derivatives were biologically evaluated to identify potent new antioxidants. Most of the evaluated compounds showed significant to modest antioxidant properties $\left(\mathrm{IC}_{50}\right.$ value $\left.399.07140 .0 \pm 50 \mu \mathrm{M}\right)$. Density Functional Theory (DFT) studies were carried out on the compounds and their corresponding free radicals. Differences in the energy of the parent compounds and their corresponding free radicals provided a good justification for the trend found in their $\mathrm{IC}_{50}$ values. In silico, docking of compounds into the proteins acetylcholinesterase (AChE) and butyrylcholinesterase (BChE), which are well known for contributing in AD disease, was also performed to predict anti-AD potential.
\end{abstract}

Uniterms: Alzheimer's disease. Antioxidant compounds. Chronic diseases. Density Functional Theory. Molecular docking. Computational studies. DPPH assay. Indole derivatives. Acetylcholinesterase (AChE). Butyrylcholinesterase (BChE).

\begin{abstract}
A doença de Alzheimer (DA) é uma doença neurodegenerativado sistema nervoso central, em rápido crescimento, e antioxidantes ajudam a suprimir o estresse oxidativo causado por radicais livres, responsávies pela DA. Avaliou-se, biologicamente, série de derivados sintéticos de indol selecionados para identificar novos antioxidantes. A maioria dos compostos avaliados apresentou de significativa a boa propriedade antioxidante (valor de $\mathrm{IC}_{50} 399,07140.0 \pm 50 \mu \mathrm{M}$ ). Eftuaram-se estudos de Teoria do Funcional de Densidade (DFT) com os compostos e os seus correspondentes radicais livres. As diferenças de energia entre os compostos protótipos e os radicais livres correspondentes proporcionaram boa justificativa para a tendência encontrada nos seus valores de $\mathrm{IC}_{50}$. $\mathrm{O}$ ancoramento in silico dos compostos com a acetilcolinesterase (AChE) e com a butirilcolinesterase (BChE), que contribuem para a DA, foi, também, realizado para prever o seu potencial anti-DA.
\end{abstract}

Unitermos: Doença de Alzheimer. Compostos antioxidantes. Doenças crônicas. Teoria do Funcional de Densidade. Ancoramento molecular. Estudos computacionais. Ensaio de DPPH. Derivados do indol. Acetilcolinesterase (AChE). Butirilcolinesterase (BChE).

\footnotetext{
*Correspondence: Muhammad Yar. Interdisciplinary Research Centre in Biomedical Materials, COMSATS Institute of Information Technology, Defence Road, Lahore, 54600, Pakistan. E-mail: drmyar@ciitlahore.edu.pk
} 


\section{INTRODUCTION}

Alzheimer's disease (AD) is a complex neurodegenerative disorder of the central nervous system and the most common form of dementia in elderly people (Scarpini, Scheltens, Feldman, 2003). Affecting over 20 million people worldwide (Suh, Suslick, Suh, 2005), it is characterized by progressive loss of cognitive and memory, speech loss and personality changes and is one of the major causes of admissions to nursing homes (Wilson et al., 2007). Moreover, the cholinergic hypothesis postulates that a decrease in acetylcholine (ACh) levels within the brain causes gradual neurodegeneration and leads to AD (Francis et al., 1999).

The oxidative stress caused by free radicals has been shown to be a main contributor to the development of Alzheimer's disease (Floyd, Hensley, 2002). Currently drugs designed to treat $\mathrm{AD}$ are based on the improvement of cholinergic neurotransmission. This increase in neurotransmission is attained through the inhibition of an enzyme responsible for acetylcholine hydrolysis, AChE, and also by the inhibition of human plasma BChE (Silva et al., 2006). The first approved drugs for the management of the disease were the cholinesterase inhibitors tacrine, donepezil, rivastigmine, and galanthamine (Figure 1). These drugs helped increase neurotransmission at cholinergic synapses in the brain and thereby improve cognition (Giacobini, 2004).

The practical efficiency of these acetylcholinesterase inhibiting drugs (AChE-I) for AD treatment remains controversial. Recent AD trials concluded that AChE-I therapies are not cost effective and show detrimental side effects. These problems have led to discontinuation in certain cases, as seen with tacrine (Petersen et al., 2005). For these reasons the interest in the development of new and potent cholinesterase inhibitors has increased in the last few years.

A number of studies have shown that in elderly people the antioxidant defense system loses its capacity to neutralize oxidative species, and this oxidative stress can act as a possible reason for the initiation and progression of AD (Floyd, Hensley, 2002). In the brains of patients with $\mathrm{AD}$, according to oxidative and nitrosylative damage hypothesis, reactive nitrogen species (RNS) and reactive oxygen species (ROS) play important roles in the initiation and promotion of neurodegeneration. Clinical studies have shown the beneficial effects of high-dose antioxidants (Sokura et al., 2005). Thus, drugs that specifically scavenge oxygen radicals may have a particular therapeutic efficacy (Tan et al., 2003), and several antioxidants<smiles>Nc1c2c(nc3ccccc13)CCCC2</smiles><smiles>COc1cc2c(cc1OC)C(=O)C(CC1CCN(Cc3ccccc3)CC1)C2</smiles><smiles>CCN(C)C(=O)Oc1cccc(C(C)C(C)C)c1</smiles><smiles>COc1ccc(CN2CC3CCC2(Cc2ccc(O)cc2)CC3)cc1</smiles>

Galanthamine

FIGURE 1 - Known drugs as cholinesterase inhibitors.

have been tested in clinical trials (Klatte et al., 2003). To design a new anti-AD agent, with potential AChE and BChE inhibitory activities, molecular modeling techniques are of great significance (Sarojini et al., 2010, 2011).

Indole alkaloids are well known due to their extensive biological importance (Inman, Moody, 2013; Yar et al., 2014b) including AChE (Monte-Millán et al., 2006; Ismail et al., 2012; Munoz-Ruiz et al., 2005) and BChE (Boga et al., 2011; Jakubowska et al., 2012; Yar et al., 2014a) inhibition activities. Compounds containing indole skeleton were also found to be the dual binding site AChE inhibitors, which in turn has a potential in disease modifying agents (Munoz-Ruiz et al., 2005) (Figure 2, a and b). Thus, there is a great deal of interest to develop dual binding site $\mathrm{AChE}$ inhibitors as a means to control AD (Monte-Millán et al., 2006; Yar et al., 2014a). Tacrine-melatonin hybrids (Figure 2, c), which were potent inhibitors of human AChE and showed high oxygen radical absorbance capacity, were also synthesized (Franco, Isabel, 2006).

Among alkaloids, indole alkaloids represent one of the most interesting class of compounds, especially pentacyclic natural indole alkaloids such as reserpine (Figure 3). Reserpine was isolated from Rauwolfia serpentina and is regarded an important pharmacological agent due to its extensive use in the treatment of hypertension and mental disorders (Chatterjee, Pakrashi, Werner, 1956; Woodson et al., 1957; Lucas et al., 1963; Monachino, 1954).

Such promising biological potential of indole 
(a)<smiles>[R][R](Cl)Cl</smiles>

(b)<smiles>[R][R](Cl)Cl</smiles>

(c)

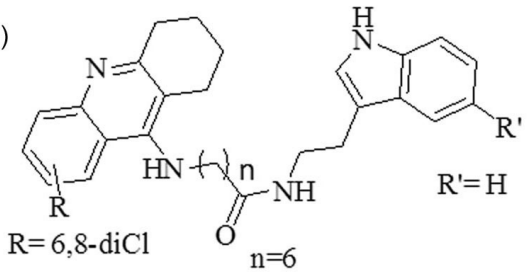

FIGURE 2 - Known indole derivatives as potent AChE inhibitors.

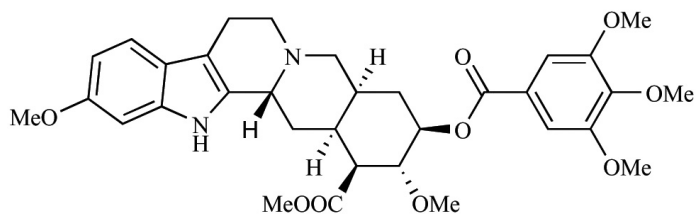

FIGURE 3 -The chemical structure of reserpine.

alkaloids has prompted us to synthesize and biologically evaluate a series of indole derivatives (Table I) to identify potent novel antioxidants. In this paper we report the synthesis of indole derivatives 1-4, their DPPH scavenging activities and DFT studies based on the calculations of the energy differences of the indole parent molecules and their corresponding free radicals. These energy differences are correlated with the $\mathrm{IC}_{50}$ values for the first time ever. In the present study, the binding modes of the newly synthesized indole alkaloid $\mathbf{2}$ (predicted to have the most anti-oxidant potential in the tested series) with $\mathrm{AChE}$ and $\mathrm{BChE}$ are also demonstrated.

\section{MATERIAL AND METHODS}

\section{Chemistry}

Indole derivatives 1-4 were prepared by following our reported procedures (Yar et al., 2012). For detailed synthetic methods and characterization of the compounds 1, 2, 3 and 4, please see our previous paper (Yar et al., 2012). The structures of the compounds 1-4 are shown in Table I.

\section{Antioxidant activity}

DPPH (1, 1-diphenyl-2-picryl hydrazyl radical) free radical scavenging activity: The reaction mixture containing $5 \mu \mathrm{L}$ of test sample ( $1 \mathrm{mM}$ in DMSO) and $95 \mu \mathrm{L}$ of DPPH (sigma, $300 \mu \mathrm{M}$ ) in ethanol was employed. The reaction mixture was taken in a 96-well micro liter plate (molecular devices, USA) and incubated in Elisa at $37^{\circ} \mathrm{C}$ for $30 \mathrm{~min}$. At the end of the incubation period the absorbance was measured at $515 \mathrm{~nm}$ using a spectrophotometer. Percent radical scavenging activity was determined by comparison with a DMSO treated control (Table I). $\mathrm{IC}_{50}$ values showed concentrations of compounds to scavenge $50 \% \mathrm{DPPH}$ radicals. BHA (3-t-butyl-4-hydroxy anisole) was used as positive control. All the chemicals used were of analytical grade purchased from Sigma-Aldrich USA.

\section{Molecular docking}

The crystal structure of AChE (PDB Id: 4EYZ) bound to donepezil and BChE (PDB Id: 4B0O) bound to benzyl pyridinium-4-methyltrichloroacetimidate were used for the docking studies. Dock Prep (Lang et al., 2009) module was used in Chimera (Pettersen et al., 2004) to delete solvent water molecules while retaining the water molecules within $5 \AA$ of the bound ligand. Adding hydrogens and repairing the truncated side chains was done by using rotamer libraries (Dunbrack et al., 2002). The prepared protein was saved in pdbqt format using Autodock Tools 1.5.6 (Morris et al., 2009). The ligand coordinates were generated by using the molecular design program TorchV10lite (http://www.cresset-group.com/ products/torch/torchlite/) and smiles were converted to 3D structure by using Openbabel (O'Boyle et al., 2011) version (2.3.1). The pdbqt files for ligands were prepared by Autodock Tools 1.5 .6 by using default parameters. Kollman charges were added to the standard residues while Gasteiger charges were added to the ligands by using the ADT tools. AUTODOCK 4 (Morris et al., 2009) was used for docking calculations with a grid box size of $40 \times 40 \times 40$ and centered on the co-crystallized ligand. For validating the docking protocol, co-crystallized ligand was docked with RMSD from reference ligand as 0.44 and 1.48 for donepezil and $15 \mathrm{~F}$, respectively. Docked poses were analyzed by using Autodock Tools 1.5.6 to get the best binding pose of compound $\mathbf{2 a}$ with the lowest binding energy and the best overlap with the co-crystallized ligand.

\section{Computational studies}

All calculations were performed with Gaussian 09 
(Frisch et al., 2009). The geometries of the structures were optimized at hybrid B3LYP method (Becke, 1993; Lee et al., 1988) with 6-31G* basis set. The method and basis set chosen provided a nice balance between cost and accuracy. The geometries of the optimized structures were visualized using Marvin View (MarvinView 5.9.4. ChemAxon.2012).

\section{RESULTS AND DISCUSSION}

The whole series of compounds (1-4) shown in Table I were screened for their antioxidant activity. Among these compounds, $\mathbf{2}$ presented the highest activity with an $\mathrm{IC}_{50}$ value of $140.0 \mu \mathrm{M}$, while compound $\mathbf{3}$, in which an $\alpha, \beta$-unsaturated double bond was converted into cisepoxide, showed the second highest activity with an $\mathrm{IC}_{50}$ of $145.8 \mu \mathrm{M}$. As compared to the $\alpha, \beta$-unsaturated ketone 2 , the activity of the $\beta, \gamma$-unsaturated ketone 1 was curtailed as its $\mathrm{IC}_{50}$ was found to be $178 \mu \mathrm{M}$. The possible reason for the lower activity in the case of compounds $\mathbf{3}$ and $\mathbf{1}$ could be due to the absence of conjugation in the ring $\mathrm{E}$. When compound 2, bearing the $\alpha, \beta$-unsaturated ketone, was converted into compound 4 , which contained a methoxy group at the $\alpha$-position, its activity was further decreased to $\mathrm{IC}_{50} 358 \mu \mathrm{M}$. The results are summarized in Table I.

\section{Computational studies}

Computational studies were carried out to correlate the structure-activity relationship of the compounds (1-4) as shown in Figure 4. Triggered by the wellestablished fact that in the DPPH assay scavenging of DPPH free radicals occurs by $\mathrm{H}$-transfer from the radical scavengers, we became interested in correlating the ease of formation of free radicals by the structures 1-4 with their corresponding $\mathrm{IC}_{50}$ values. Only the ring E offers the structural variation in all the four structures and hence it is expected to be responsible for the variations of $\mathrm{IC}_{50}$ values. The energies of the optimized structures 1-4 and their corresponding proposed free radicals were calculated. We thought that a free radical with higher energy would be more difficult to form. For this purpose we compared the energies of free radicals for each molecule with their parent molecule, Table I. It is noted that their differences justify the trend found in their $\mathrm{IC}_{50}$ values. The greater the energy difference between a free radical and its parent molecule the more difficult it is for the molecule to offer a proton to scavenge the DPPH free radical; hence the molecule must exhibit less oxidant potential and have a higher $\mathrm{IC}_{50}$ value as a consequence. Indole 4 shows the

TABLE I - The quantitative estimation of antioxidant activity of the indole derivatives $\mathrm{IC}_{50}$ values are means of three independent experiments (Mean \pm SEM, $\mathrm{n}=3$ )

\begin{tabular}{|c|c|c|c|c|c|c|}
\hline Sr No. & $\begin{array}{c}\% \text { Scavenging } \\
\text { activity of DPPH } \\
\text { at } 1000 \mu \mathrm{M}\end{array}$ & $\mathrm{IC}_{50}(\mu \mathrm{M})$ & $\begin{array}{c}\text { Energy of parent } \\
\text { molecule (au) }\end{array}$ & $\begin{array}{l}\text { Energy of free } \\
\text { radical (au) }\end{array}$ & $\begin{array}{l}\text { Energy difference } \\
\text { between parent } \\
\text { molecule and } \\
\text { radical }(\mathrm{kcal} / \mathrm{mol})\end{array}$ & Structures \\
\hline
\end{tabular}

1

79.08

178.0

$-1035.34$

$-1034.71$

392.70

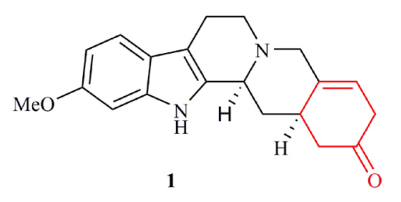

2

79.9

140.0

$-1035.31$

$-1034.71$

375.65
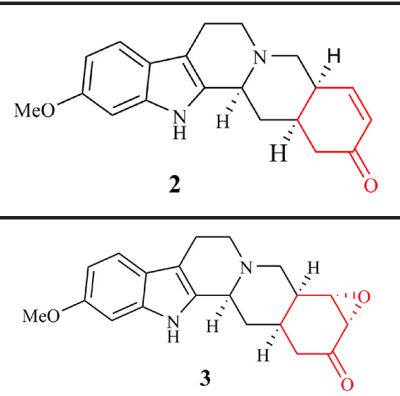

3

85.7

145.8

$-1110.54$

$-1109.92$

386.85

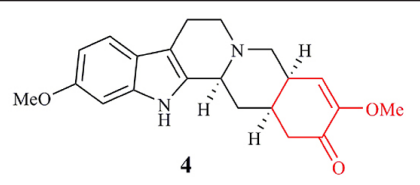

$-1149.24$

392.90
$-1149.86$ 


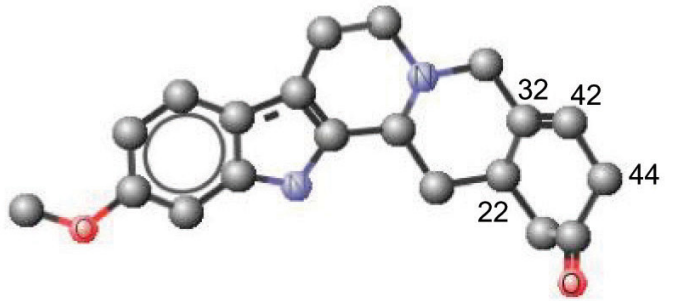

Indole 1

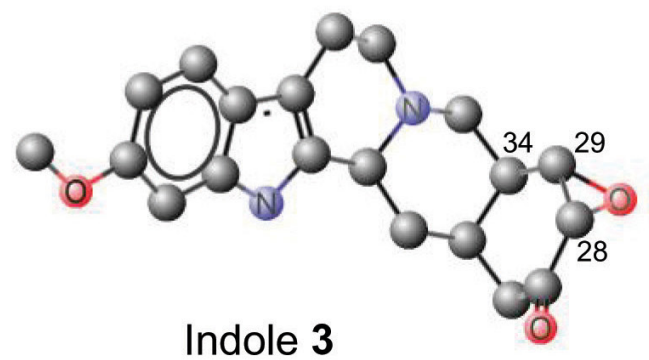

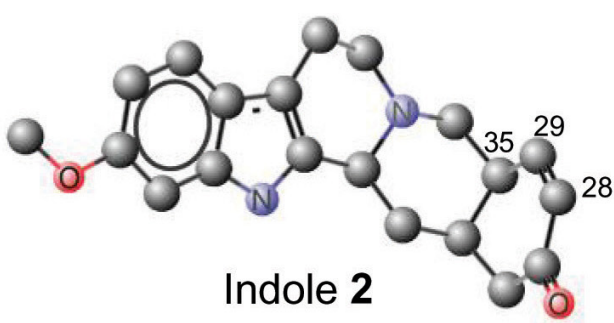

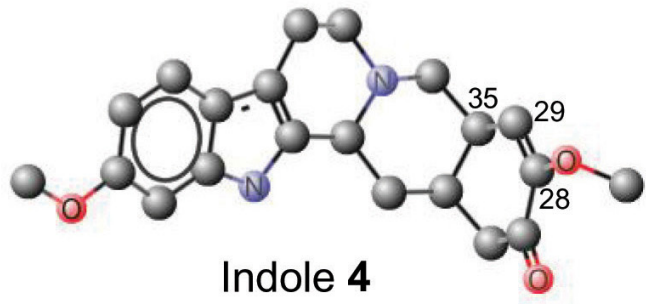

FIGURE 4 - Optimized geometries of the optimized compounds 1-4.

highest $\mathrm{IC}_{50}$ value (less potent) due to the highest energy difference. The lowest energy difference and lowest $\mathrm{IC}_{50}$ value were observed for the molecule 2 , thus it had the highest antioxidant potential. In the structures 2 and 4 , only one energetically favorable site (C-35) is available from where hydrogen abstraction would take place. In indole 1, a hydrogen atom abstracted from the position C-44 shows more stability and this is consistent with the $\mathrm{IC}_{50}$ value observed experimentally. Similarly, for the indole $\mathbf{3}$, hydrogen abstraction is believed to occur from C-28. This ultimately leads to ring opening of the epoxide.

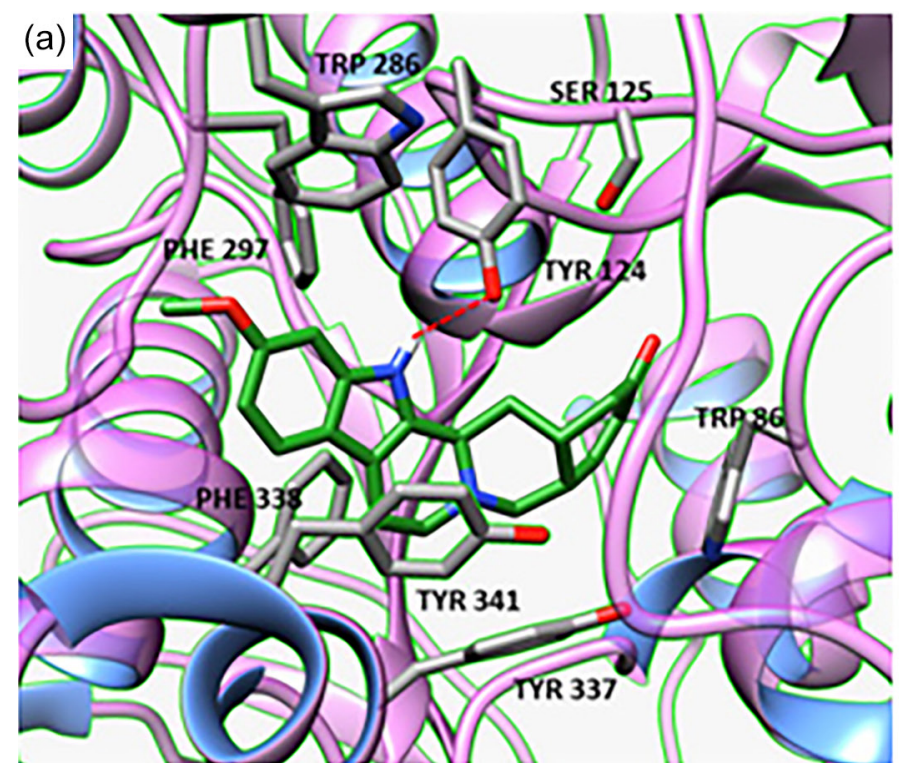

\section{Molecular modelling}

AChE docking

All the compounds (1-4) were docked in the crystal structure of AChE (PDB Id : 4EYZ) by using AUTODOCK 4 (Morris et al., 2009; Pettersen et al., 2004). The docking conformation of compound $\mathbf{2}$ overlaps very well with the crystal structure conformation of donepezil bound to Acetylcholinesterase (PDB : 4EYZ) (Figure 5).

The N-H in the indole forms a hydrogen bond with Tyr 124 . There are three $\pi-\pi$ interactions present such as

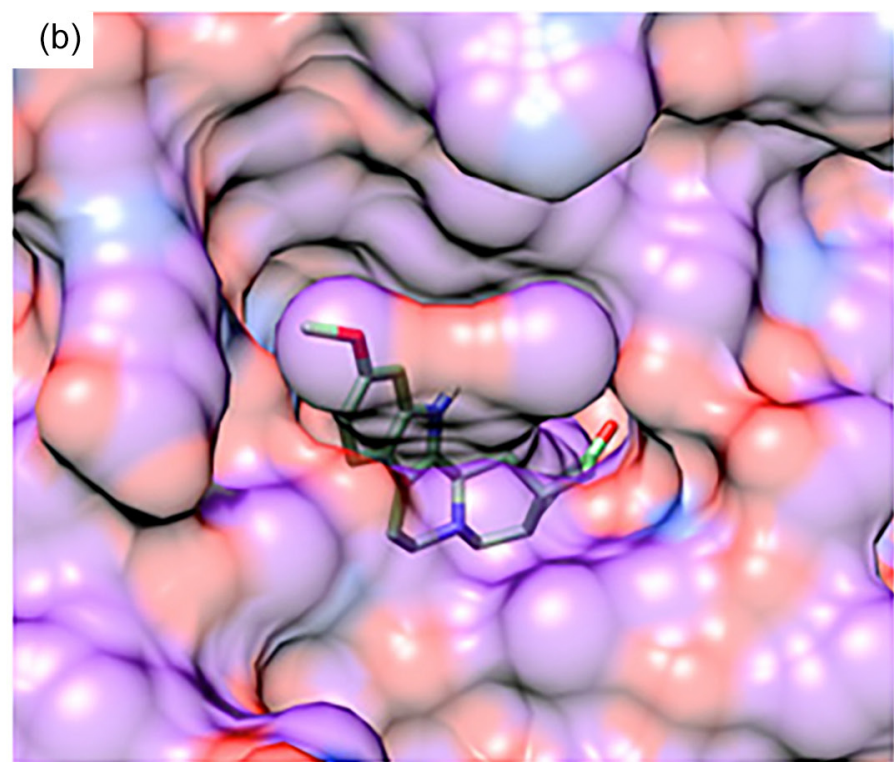

FIGURE 5 - (a) Docked binding mode of indole derivative 2 with AChE (PDB : 4EYZ); (b) The ligand molecule 2 buried in the AChE active pocket. 
TABLE II -The docking results for ligand molecule $\mathbf{2}$ against $\mathrm{AChE}$ and $\mathrm{BChE}$

\begin{tabular}{cccccccc}
\hline Protein & Compound & H- bonds & $\begin{array}{c}\text { Binding Energy } \\
(\mathrm{kcal} / \mathrm{mole})\end{array}$ & Protein & Compound & H- bonds & $\begin{array}{c}\text { Binding Energy } \\
(\mathrm{kcal} / \mathrm{mole})\end{array}$ \\
\hline \multirow{6}{*}{$\mathrm{AChE}$} & 1 & 1 & -11.00 & & 1 & 2 & -8.48 \\
& 2 & 1 & -10.75 & & 2 & 3 & -8.86 \\
& 3 & 2 & -10.76 & & 3 & 2 & -8.19 \\
& 4 & 1 & -11.00 & BChE & 4 & 1 & -8.50 \\
\hline
\end{tabular}

with Tyr 341, Phe 338 and Trp 86. Compound 2 mostly forms hydrophobic interactions in addition to 1 hydrogen bond within the active site. The docking binding energy is $-10.75 \mathrm{kcal} / \mathrm{mol}$ as compared to $-11.72 \mathrm{kcal} / \mathrm{mol}$ for donepezil.

\section{BChE docking}

Similarly, we docked compound $\mathbf{2}$ in the crystal structure of BChE (PDB Id: 4B0O). The docked pose of 2 overlaps very well with the bound benzyl pyridinium4-methyltrichloroacetimidate (PDB Id: 15F) (Figure 6). The free energy of binding was estimated to be -8.86 $\mathrm{kcal} / \mathrm{mol}$ and $-6.60 \mathrm{kcal} / \mathrm{mol}$ for 2 and pyridinium4-methyltrichloroacetimidate $(15 \mathrm{~F})$, respectively. Compound 2 forms 3 hydrogen bonds with Trp 82 and Trp 440 on one side and the $-\mathrm{OCH}_{3}$ functional group forms hydrogen bond with water (W2013) on the other side. A dual binding site was not observed for this compound.

The docking of ligand molecule 2 with $\mathrm{AChE}$ (PDB
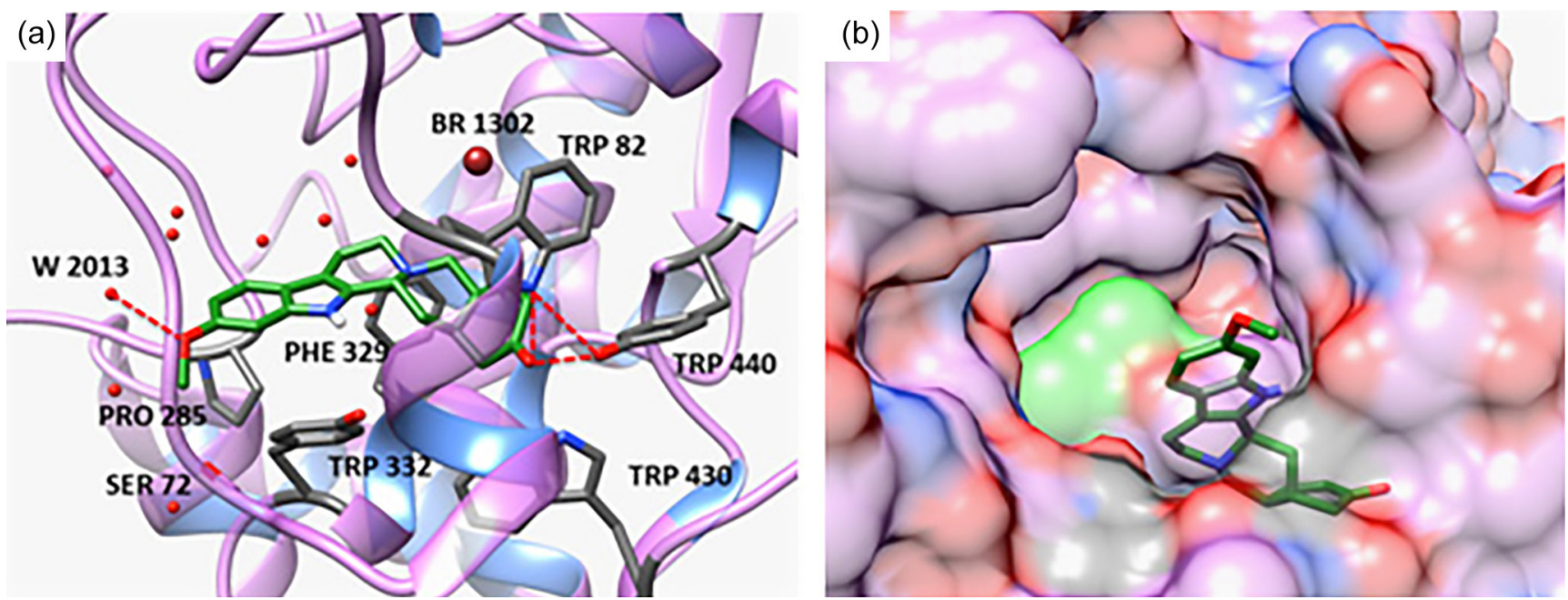

FIGURE 6 -(a) Docked binding mode of indole derivative 2 with BChE (PDB : 4B0O); (b) The ligand molecule 2 buried in the $\mathrm{BChE}$ active pocket. 
greater potency and we are currently conducting research on this matter. In silico, docking of compounds into the proteins (Acetylcholinesterase and Butyrylcholinesterase), which are well known for contributing to AD disease, was also performed to predict their $\mathrm{AChE}$ and $\mathrm{BChE}$ inhibition potential. Among all of the compounds (1-4), compound 2 showed the best inhibition of both AChE and BChE.

\section{ACKNOWLEDGMENTS}

Authors acknowledge Prof Dr M. I. Chaudhary for his support and guidance and Higher Education Commission of Pakistan for financial support. Molecular graphics and analyses were performed with the UCSF Chimera package. Chimera is developed by the Resource for Biocomputing, Visualization, and Informatics at the University of California, San Francisco (supported by NIGMS P41-GM103311).

\section{REFERENCES}

BECKE, A.D. Density-functional thermochemistry. III. The role of exact exchange. J. Chem.Phy.,v.98, p.5648, 1993.

BOGA, M.; KOLAK, U.; TOPCU, G.; BAHADORI, F.; KARTAL, M.; FARNSWORTH, N.R.Two new indole alkaloids from Vincaherbacea L. Phytochem. Lett., v.4, p.399-403, 2011.

CHATTERJEE, A.; PAKRASHI, S.; WERNER, G. Recent developments in the chemistry and pharmacology of rauwolfia alkaloids. Progress Chem. Nat. Prod.v.13, p.346, 1956.

DUNBRACK, R. Jr. Rotamer libraries in the 21 st century. Curr. Opin. Struct. Biol., v.12, p.431-440, 2002.

FRANCO, R.; ISABEL, M. Novel tacrine-melatonin hybrids as dual-acting drugs for Alzheimer disease, with improved acetylcholinesterase inhibitory and antioxidant properties. J. Med. Chem.,v.49, p.459-462, 2006.

FRANCIS, P.T.; PALMER, A.M.; SNAPE, M.; WILCOCK, G.K. The cholinergic hypothesis of Alzheimer's disease: A review of progress. J. Neurol. Neurosurg. Psychiatry, v.66, p.137-147, 1999.

FLOYD, R.A.; HENSLEY, K. Oxidative stress in brain aging. Implications for therapeutics of neurodegenerative diseases. Neurobiol. Aging, v.23, p.795-807, 2002.
FRISCH, M.J.; TRUCKS, G.W.; SCHLEGEL, H.B.; SCUSERIA, G.E.; ROBB, M. A.; CHEESEMAN; J. R. SCALMANI; G.; BARONE; V. MENNUCCI; B. PETERSSON; G. A. NAKATSUJI; H. CARICATO; M.; LI, X.; HRATCHIAN; H. P. IZMAYLOV; A. F. BLOINO; J. ZHENG; G. SONNENBERG; J. L. HADA, M.; M. EHARA; K. TOYOTA; R. FUKUDA; HASEGAWA; M. ISHIDA; T. NAKAJIMA; Y. HONDA; O. KITAO; H. NAKAI; T. VREVEN; J. A. MONTGOMERY; JR., J. E. P.; F. OGLIARO; M. BEARPARK; J. J. HEYD; E. BROTHERS; K. N. KUDIN; V. N. STAROVEROV; R. KOBAYASHI; J. NORMAND; K. RAGHAVACHARI; A. RENDELL; J. C. BURANT; S. S. IYENGAR; J. TOMASI; M. COSSI; N. REGA; J. M. MILLAM; M. KLENE; J. E. KNOX; J. B. CROSS; V. BAKKEN; C. ADAMO; J. JARAMILLO; R. GOMPERTS; R. E. STRATMANN; O. YAZYEV; A. J. AUSTIN; R. CAMMI; C. POMELLI; J. W. OCHTERSKI; R. L. MARTIN; K. MOROKUMA; V. G. ZAKRZEWSKI; G. A. VOTH; P. SALVADOR; J. J. DANNENBERG; S. DAPPRICH; A. D. DANIELS; Ö. FARKAS; J. B. FORESMAN; J. V. ORTIZ; CIOSLOWSKI, J.; FOX, D. J. Gaussian, Inc., 09, revision A.1, Wallingford CT, 2009.

GIACOBINI, E. Cholinesterase inhibitors: new roles and therapeutic alternatives. Pharmacol. Res.,v.50, p.433-440, 2004.

INMAN, M.; MOODY, C.J. Indole synthesis - something old, something new. Chem. Sci., v.4, p.29-41, 2013.

ISMAIL, M.M.; KAMEL, M.M.; MOHAMED L.W.; FAGGAL S.I.Synthesis of new indole derivatives structurally related to donepezil and their biological evaluation as acetylcholinesterase inhibitors. Molecules, v.17, p.48114823, 2012.

JAKUBOWSKA, A.; KULIG, K.; GUZIOR, N.; MALAWSKA, B. Synthesis of novel N-benzyl substituted piperidine amides of $1 \mathrm{H}$-indole-5-carboxylicacid as potential inhibitors of cholinester. Acta. Pol. Pharm., v.69, p.449-55, 2012.

KLATTE, E. T.; SCHARRE, D. W.; NAGARAJA, H. N.; DAVIS, R. A.; BEVERSDORF, D. Q. Combination therapy of donepezil and vitamin $\mathrm{E}$ in Alzheimer disease. Alzheimer Dis. Assoc. Disord.,v.17, p.113-116, 2003.

LANG P.T.; BROZELL, S.R.; MUKHERJEE, S.; PETTERSEN, E.F.; MENG E.C., THOMAS, V.; RIZZO, R.C.; CASE, D.A.; JAMES, T.L.; KUNTZ, I.D. Dock 6: combining techniques to model RNA-small molecule complexes. $R N A ., \mathrm{v} .15$, p.1219-1230, 2009. 
LEE, C.; YANG, W.; PARR, R.G. Development of the ColleSalvetti correlation-energy formula into a functional of the electron density.Physical Rev. B, v.37, p.785-789. 1988.

LUCAS, R.A.The chemistry and pharmacologyof theRauwolfia alkaloids.Prog. Med. Chem., v.19, p.146-186, 1963.

MONACHINO, J. Rauvolfiaserpentina - its history, botany, and medical use.Economic Bot.,v.8, p.349-365, 1954.

MONTE-MILLÁN, M.; GARCÍA-PALOMERO, E.; VALENZUELA, R.; USÁN, P.; DE AUSTRIA, C.; MUÑOZ-RUIZ, P.; RUBIO, L.; DORRONSORO, I.; MARTÍNEZ, A.; MEDINA, M. Dual binding site acetylcholinesteraseinhibitors. J. Mol. Neurosci., v.30, p.85-87, 2006.

MORRIS, G. M.; HUEY, R.; LINDSTROM, W.; SANNER, M. F.; BELEW, R.K.; GOODSELL, D. S.; OLSON, A.J. Auto dock4 and auto dock tools4: automated docking with selective receptor flexibility. J.Comput.Chem., v.30, p.2785-2791, 2009.

MUNOZ-RUIZ, P.M.; RUBIO, L.; GARCIA-PALOMERO, E.; DORRONSORO, I.; DEL MONTE-MILLAN, M.; VALENZUELA, R.; USAN, P.; DE AUSTRIA, C.; BARTOLINI, M.; ANDRISANO, V.; BIDONCHANAL, A.; OROZCO, M.; LUQUE, F.J.; MEDINA, M.; MARTINEZ, A. Design, synthesis, and biological evaluation of dual binding site acetylcholinesterase inhibitors: new disease-modifying agents for Alzheimer's disease. J. Med. Chem., v.48, p.7223-7233, 2005.

O'BOYLE, M.; BANCK, M.; JAMES, C.A.; MORLEY, C.; VANDERMEERSCH, T.; HUTCHISON, G.R. Open Babel: an open chemical toolbox, J. Chem. Inform.,v.3, p.33, 2011.

PETTERSEN, E.F.; GODDARD, T.D.; HUANG, C.C.; COUCH, G.S.; GREENBLATT, D.M.; MENG, E.C.; FERRIN, T.E. UCSF chimera-a visualization system for exploratory research and analysis. J. Comput. Chem.,v.25, p.1605-1612, 2004.

PETERSEN, R.C.; THOMAS, R.G.; GRUNDMAN, M.; BENNETT, D.; DOODY, R.; FERRIS, S.; ALASKO, D.; JIN, S.; KAYE, J.; LEVEY, A.; PFEIFFER, E.; SANO, M.; VAN DYCK, C.H.; THAL, L.J. Vitamin E and donepezil for the treatment of mild cognitive impairment. N. Engl. J. Med., v.352, p. 2379-2388, 2005
SAROJINI, B.K.; RAJ, C.G.D.; RAMAKRISHNA, M.K.; RAMESH, S.R.; BHARATH, B.R.; MANJUNATHA, H. .In Silico studies of (2E,5E)-2,5-bis(3-methoxy-4-hydroxybenzylidene) cyclopentanone on proteins $\mathrm{AChE}$ and $\mathrm{BChE}$ involved in Alzheimer's disease and ameliorative effects on paraquat induced oxidative stress markers in drosophila melanogaster. Lett. Drug Des. Discov.,v.8, p.260-267, 2011.

SAROJINI, B.K.; VIDYAGAYATRI, M.; DARSHANRAJ, C.G.; BHARATH, B.R.; MANJUNATHA, H. DPPH scavenging assay of novel 1,3-disubstituted-1H-pyrazol5-ols and their in silicostudies on some proteins involved in Alzheimer's disease signaling cascade. Lett. Drug Des. Discov.,v.7, p.214-224, 2010.

SCARPINI, E.; SCHELTENS, P.; FELDMAN, H. Treatment of Alzheimer'sdisease: current status and new perspectives. Lancet Neurol.,v.2, p.539-547, 2003.

SILVA, C.H.T.P.; CAMPO, V.L.; CARVALHO, I.; TAFT, C.A. Molecular modeling, docking and ADMET studies applied to the design of a novel hybrid for treatment of Alzheimer's disease. J. Mol. Graph Mod., v.25,p.169-175,2006.

SOKURA, S.; YOSHIDA, N.; SAKAMOTO, N.; ISHIKAWA, T.; TAKAGI, T.; HIGASHIHARA, H.; NAKABE, N.; HANDA, O.; NAITO, Y.; YOSHIKAWA, T.The radical scavenger edaravone. Cancer Lett., v.229, p.223-233.2005.

SUH, W.H.; SUSLICK, K.S.; SUH, Y.H. Therapeutic agents for Alzheimer's disease.Curr. Med. Chem. - Cent. Nerv. Syst. Agent, v.5, p.259-269, 2005.

TAN, D.-X.; MANCHESTER, L.C.; SAINZ, R.; MAYO, J.C.; ALVARES, F.L.; REITER, R. J.antioxidant strategies in protection against neurodegenerative disorders. Expert. Opin. Ther. Pat., v.13, p.1513-1543, 2003.

WILSON, R.S.; MCCANN, J.J.; LI, Y., AGGARWAL N.T.; GILLEY, D.W.; EVANS, D.A. Nursing home placement, day care use, and cognitive decline in Alzheimer's disease. Am. J. Psychiatry, v.164,p.910-915, 2007.

WOODSON, R. E.; YOUNGKEN, H. W.; SCHLITTLER, E.; SCHNEIDER, J. Rauwolfia: Botany, pharmacognosy, chemistry and pharmacology. Boston: Little, Brown \& Co., 1957. 
YAR, M.; ARSHAD, M.; AKHTAR, M. N.; SHAHZAD, S.A.; KHAN, I.U.; KHAN, Z.A.; ULLAH, N.; NINOMIYA, I., Studies towards the synthesis of $( \pm)$-reserpine: photocyclization mediated a novel and efficient synthesis of 11, 18-dimethoxy-(20 $)$-18, 19-didehydro-yohimban17-one. Eur. J. Chem., v.3, p.26-31, 2012.

YAR, M.; BAJDA, M.; MEHMOOD, R.A.; SIDRA, L.R.; ULLAH, N.; SHAHZADI, L.; ASHRAF, M.; ISMAIL, T.; SHAHZAD, S.A.; KHAN, Z.A.; NAQVI, S.A.R.; MAHMOOD, N. Design and synthesis of new dual binding site cholinesterase inhibitors: in vitro inhibition studies with in silico docking. Lett. Drug Des. Discov.,v.11, p.331-338, 2014a.
YAR, M.; SIDRA, L.; PONTIKI, E.; MUSHTAQ, N.; ASHRAF, M.; NASAR, R.; KHAN, I.U.; MAHMOOD, N.; NAQVI, S. A.R.; KHAN, Z.A.; SHAHZAD, S.A. Synthesis, in vitro lipoxygenase inhibition, docking study and thermal stability analyses of novel indole derivatives. J. Iran Chem. Soc., v.11, p.369-378, 2014b.

Received for publication on $22^{\text {nd }}$ January 2014 Accepted for publication on $04^{\text {th }}$ August 2014 
